\title{
Anodic Polarization Behavior of Titanium Grade 7 in Dust Deliquescence Salt Environments
}

K. J. Evans, R. B. Rebak

March 12, 2007

2007 ASME Pressure Vessels and Piping Division Conference San Antonio, TX, United States July 22, 2007 through July 27, 2007 
This document was prepared as an account of work sponsored by an agency of the United States Government. Neither the United States Government nor the University of California nor any of their employees, makes any warranty, express or implied, or assumes any legal liability or responsibility for the accuracy, completeness, or usefulness of any information, apparatus, product, or process disclosed, or represents that its use would not infringe privately owned rights. Reference herein to any specific commercial product, process, or service by trade name, trademark, manufacturer, or otherwise, does not necessarily constitute or imply its endorsement, recommendation, or favoring by the United States Government or the University of California. The views and opinions of authors expressed herein do not necessarily state or reflect those of the United States Government or the University of California, and shall not be used for advertising or product endorsement purposes. 


\title{
Proceedings of PVP2007 \\ 2007 ASME Pressure Vessels and Piping Division Conference July 22-26, 2007, San Antonio, Texas PVP200726161
}

\section{ANODIC POLARIZATION BEHAVIOR OF TITANIUM GRADE 7 IN DUST DELIQUESCENCE SALT ENVIRONMENTS}

\author{
Kenneth J. Evans $\quad$ Raul B. Rebak \\ Lawrence Livermore National Laboratory \\ Livermore, California, 94550 USA
}

\begin{abstract}
It is planned to use the highly corrosion resistant titanium grade 7 ( Ti Gr 7) and a high strength titanium alloy (Ti Gr 29) to fabricate the drip shield for the Yucca Mountain repository. Ti Gr 7 contains $0.15 \%$ Palladium (Pd) to increase its corrosion performance, mainly under reducing conditions. It was important to determine the corrosion behavior of $\mathrm{Ti} \mathrm{Gr} 7$ in concentrated brines at temperatures higher than $100^{\circ} \mathrm{C}$, which may represent the behavior of dust deliquescence solutions. Tests were performed in concentrated $\mathrm{NaCl}+\mathrm{KCl}$ solutions containing also nitrates and fluorides. Results show that Ti Gr 7 was highly resistant to general and localized corrosion. Some specimens were polarized to potentials higher than 4 volts. None of the tightly creviced specimens suffered crevice corrosion. The presence of fluoride promoted localized corrosion around the edges of the crevice former.
\end{abstract}

Keywords: Ti Gr 7, corrosion, dust, chloride, nitrate, fluoride

\section{INTRODUCTION}

In its current design, the drip shields for the high-level nuclear waste containers for the Yucca Mountain repository will be made using mainly Ti Gr 7 (R52400) [1]. Ti Gr 7 is a highly corrosion resistant alloy, especially because it contains $0.15 \%$ palladium $(\mathrm{Pd})$ [2]. The higher strength Ti Gr 29 [2] will be used for structural support of the drip shield.

Titanium and $\mathrm{Ti}$ alloys have excellent corrosion resistance due to the presence of a highly adherent and continuous oxide film that develops on the surface of the fabricated components [3]. If the film is damaged, the high affinity of Ti for oxygen causes this film to reform instantly even in presence of small amounts of oxygen or moisture. This protective oxide film is basically $\mathrm{TiO}_{2}$. Ti alloys have a broad range of application in the industry as corrosion resistant materials. Uses include seawater, wet chlorine, chlorinated organic compounds and oxidizing acids (e.g. nitric and chromic acids). Some of the media in which $\mathrm{Ti}$ should not be used include hydrofluoric acid, dry chlorine and hot pure sulfuric acid solutions.

The addition of small amounts of alloying elements (2-3\%) to titanium does not alter the protective stability of the oxide film on $\mathrm{Ti}$ [3]. Also, the addition of small amounts of platinum group metals (PGM) such as $\mathrm{Pd}, \mathrm{Ru}$, etc. reduces considerably the general corrosion rate of $\mathrm{Ti}$ in reducing acids [3-5]. Some $\mathrm{Ti}$ alloys may be susceptible to crevice corrosion under certain conditions; however, $\mathrm{Ti}$ alloys are practically immune to pitting corrosion in chloride solutions under most practical applications. It has been suggested that the susceptibility to crevice corrosion is due to the formation of low $\mathrm{pH}$ reducing solution under occluded conditions. Under reducing conditions the corrosion rate of $\mathrm{Ti}$ is higher than under oxidizing conditions [5]. Halide and sulfate containing solutions may induce crevice corrosion in $\mathrm{Ti}$ at temperatures higher than $70^{\circ} \mathrm{C}$ [5]. Anodic polarizations of Ti Gr 7 in 1 molar (M) chloride and fluoride containing solutions at $95^{\circ} \mathrm{C}$ have shown that the presence of fluoride produces significantly higher current densities at potentials above the corrosion potential [6-8]. The presence of fluoride may have also rendered Ti Gr 7 more susceptible to crevice corrosion under anodic polarizations [6].

Corrosion of the drip shield at the repository site may occur only in the presence of water. There are two possible sources of water that may contact the container at the repository site, seepage from the drift walls; or, deliquescence of salt and dust that may have accumulated during the initial dry periods. Deliquescence of salt mixtures will be the primary source of aqueous solution that may contact and react with the drip shield surfaces at temperatures above that for boiling of water (during the repository initial thermal period). Highly soluble salts such 
as potassium nitrate can produce concentrated solutions that could remain liquid to temperatures higher than $150^{\circ} \mathrm{C}$ at ambient pressure [9]. Chloride and nitrate salts based on the metals potassium and sodium are contained in dust that may be present at the Yucca Mountain repository site [10]. The majority of the aqueous solutions that are predicted to form on the drip shield due to dust deliquescence will consist of chloride and nitrate salts of sodium and potassium, and, in some cases, calcium [9,10]. Recent work indicates that deliquescence of these salt mixtures can occur at temperatures in excess of $180^{\circ} \mathrm{C}$, even at a low relative humidity of $10-20 \%$ $[9,10]$.

The goal of the current study was to examine the corrosion resistance of $\mathrm{Ti} \mathrm{Gr} 7$ in highly concentrated solutions that may be representative of dust deliquescence conditions. The effect of addition of fluoride has also been studied. Future studies will focus on the resistance to corrosion of air annealed titanium alloys and on Ti Gr 7 and Ti Gr 29 welds.

\section{EXPERIMENTAL}

Table 1 shows the nominal chemical composition of Ti Gr 7 specimens prepared for the tests. The heat number of this lot was CN0171.

Table 1. Chemical Composition (in wt.\%) of Ti Gr 7

\begin{tabular}{|c|c|c|c|c|c|c|}
\hline $\mathrm{Ti}$ & $\mathrm{Pd}$ & $\mathrm{Fe}$ & $\mathrm{C}$ & $\mathrm{O}$ & $\mathrm{N}$ & $\mathrm{H}$ \\
\hline$>99$ & 0.17 & 0.06 & 0.01 & 0.16 & 0.01 & 0.003 \\
\hline
\end{tabular}

The nominal composition of Ti Gr 7 is also given in ASTM standard B 265 [2]. The specimens used for corrosion testing were prism crevice assemblies (PCA). These specimens were $19 \times 19 \times 9.5 \mathrm{~mm}$ with a hole in the middle to attach the crevice formers (CF) (Figure 1). Each specimen was wet ground with 600 -grit $\mathrm{SiC}$ paper, and then ultrasonically cleaned in de-ionized water just before testing. Each specimen was then sandwiched by a pair of serrated ceramic crevice formers (ASTM G 78) [11], using a Ti Gr 2 bolt and nut to apply the desirable tightness or torque (70 in.lb). Part of the Ti bolt was sleeved with Teflon tubing to prevent the bolt from making electrical contact with the test specimen. The specimen was then mounted in a specimen holder with electrical connection to run the polarization studies (Figure 1). The final exposed surface area for the specimen after the crevice assembling was $14.06 \mathrm{~cm}^{2}$.

A three-electrode cell (Figure 2), with a capacity of one liter, was used for all the experiments. Generally, $800 \mathrm{~mL}$ of electrolyte solution was used in each test. The electrolytes had to be prepared in each test cell since these solutions are not fully soluble at ambient temperature. A saturated silver/silver chloride $(\mathrm{Ag} / \mathrm{AgCl}$, pre-filled with $4 \mathrm{M} \mathrm{KCl}$ saturated with
$\mathrm{AgCl})$ reference electrode was used for measuring the potential of the working electrode. A solution bridge of $3 \mathrm{~m} \mathrm{NaCl}+3 \mathrm{~m}$ $\mathrm{KCl}$ with a Luggin probe was used to maintain an ionic conductive path between the working electrode and the reference electrode, while a cooling jacket was used to maintain the reference electrode at near room temperature. A platinum (Pt) sheet welded to a $\mathrm{Pt}$ wire was used as a counter electrode. The electrochemical cell was heated using a heating mantle. Nitrogen gas was bubbled through the test solution for deaeration. The gas exited the cell though a condenser and a liquid trap to prevent evaporation of the solution and the ingress of air into the test cell. The deaeration was started 24 hour before the electrochemical tests. During this period the evolution of the corrosion potential was monitored. The electrochemical polarization measurements were conducted through a commercial potentiostat that was integrated with a desktop computer and the companion software.

The six test solutions used in this study are listed in Table 2. These electrolytes were highly concentrated having from $35 \%$ to $88 \%$ weight percent of salt in the solution. All the tests were carried at ambient pressure.

Table 2. Testing Matrix

\begin{tabular}{|c|c|c|c|c|}
\hline Specimen & $\begin{array}{l}\text { Brine } \\
\text { Number }\end{array}$ & Electrolyte & $\mathrm{T}^{\circ} \mathrm{C}$ & $R=\frac{\left[\mathrm{NO}_{3}^{-}\right.}{\left[\mathrm{Cl}^{-}\right.}$ \\
\hline $\begin{array}{l}\text { TG0206, } \\
\text { TG0214 }\end{array}$ & 1 & $\begin{array}{l}4 \mathrm{~m} \mathrm{NaCl}+4 \mathrm{~m} \\
\mathrm{KCl}\end{array}$ & 110 & 0 \\
\hline $\begin{array}{l}\text { TG0209, } \\
\text { TG0212 }\end{array}$ & 2 & $\begin{array}{l}4 \mathrm{~m} \mathrm{NaCl}+4 \mathrm{~m} \\
\mathrm{KCl}+1.6 \mathrm{mNO}_{3}\end{array}$ & 110 & 0.2 \\
\hline $\begin{array}{l}\text { TG0208, } \\
\text { TG0211 }\end{array}$ & 3 & $\begin{array}{l}6 \mathrm{~m} \mathrm{NaCl}+6 \mathrm{~m} \\
\mathrm{KNO}_{3}\end{array}$ & 110 & 1 \\
\hline $\begin{array}{l}\text { TG0207, } \\
\text { TG0215 }\end{array}$ & 4 & $\begin{array}{l}4 \mathrm{~m} \mathrm{NaCl}+4 \mathrm{~m} \\
\mathrm{KCl}+0.1 \mathrm{~m} \mathrm{NaF}\end{array}$ & 110 & 0 \\
\hline $\begin{array}{l}\text { TG0210, } \\
\text { TG0213 }\end{array}$ & 5 & $\begin{array}{l}4 \mathrm{~m} \mathrm{NaCl}+4 \mathrm{~m} \\
\mathrm{KCl}+1.6 \mathrm{~m} \mathrm{KNO}_{3} \\
+0.1 \mathrm{~m} \mathrm{NaF}\end{array}$ & 110 & 0.2 \\
\hline $\begin{array}{l}\text { TG0205, } \\
\text { TG0216 }\end{array}$ & 6 & $\begin{array}{l}1.5 \mathrm{~m} \mathrm{NaCl}+1.5 \mathrm{~m} \\
\mathrm{KCl}+37.5 \mathrm{~m} \\
\mathrm{NaNO}_{3}+37.5 \mathrm{~m} \\
\mathrm{KNO}_{3}\end{array}$ & 140 & 25 \\
\hline
\end{tabular}

The electrochemical test sequence consisted of three steps; (1) Monitoring the corrosion potential for $24 \mathrm{~h}$, (2) Three consecutive polarization resistance tests (ASTM G 59 and G 102) [11] and (3) A cyclic potentiodynamic polarization (CPP) 
(ASTM G 61) [11] or a Tsujikawa Hisamatsu Electrochemical (THE) test.

For the polarization resistance and the CPP polarization tests, a potential scan rate of $600 \mathrm{mV}$ per hour $(0.167 \mathrm{mV} / \mathrm{s})$ was used. In the polarization resistance tests the potential was scanned from $20 \mathrm{mV}$ below the instantaneous corrosion potential to $20 \mathrm{mV}$ above the corrosion potential. This test lasts approximately 3 minutes. For the CPP tests the scan was started at $100 \mathrm{mV}$ below the instantaneous corrosion potential and the scan was reversed when the current density reached $5 \mathrm{~mA} / \mathrm{cm}^{2}$ or $6 \mathrm{~V}$. From the CPP tests several parameters can be obtained. These are grouped into (1) Breakdown potentials (E20 and E200, which are the potentials in the forward scan that need to be reached to obtain current densities of 20 and $200 \mu \mathrm{A} / \mathrm{cm}^{2}$ respectively) and (2) Repassivation potentials (ER10, ER1 and ERCO). ER10 and ER1 are the potentials in the reverse scan that need to be reached to obtain current densities of 10 and 1 $\mu \mathrm{A} / \mathrm{cm}^{2}$. ERCO is the potential at which the reverse scan crosses over (CO) the forward scan.

For the THE tests the potentiodynamic scan was also started $100 \mathrm{mV}$ below the corrosion potential and it was switched to galvanostatic mode when the current density reached $5 \mu / \mathrm{cm}^{2}$. The galvanostatic treatment of $5 \mu / \mathrm{cm}^{2}$ was maintained for 4 hours to promote the formation of crevice corrosion. After the galvanostatic treatment the polarization was switched to potentiostatic mode applying subsequently lower $10 \mathrm{mV}$ steps.

The corrosion current $\left(\mathrm{i}_{\text {corr }}\right)$ was calculated from the polarization resistance tests using a non-linear fit of the polarization resistance test of voltage (E) vs. current $\left(i_{\text {app }}\right)$ using the following equation [12]

$i_{\text {app }}=i_{\text {corr }}\left(\exp \left[\frac{2.3\left(E-E_{\text {corr }}\right)}{\beta_{a}}\right]-\exp \left[\frac{-2.3\left(E-E_{\text {corr }}\right)}{\beta_{c}}\right]\right)$

where $E_{\text {corr }}$ is the corrosion potential and $\beta \mathrm{a}$ and $\beta \mathrm{c}$ are the Tafel constants. By fitting Eq. (1) to the acquired data, $\mathrm{i}_{\text {corr }}, \beta \mathrm{a}$ and $\beta \mathrm{c}$ were calculated simultaneously. The corrosion rate was calculated by transforming the corrosion current into corrosion rate using the Faraday equation given in ASTM G 102 [11]

$$
C R(\mathrm{~mm} / \text { year })=K_{1} \frac{i_{\text {corr }}}{\rho} E W
$$

where $i_{\text {corr }}$ is the corrosion current density in $\mu \mathrm{A} / \mathrm{cm}^{2}, \mathrm{~K}_{1}$ is a constant $\left(3.27 \times 10^{-3} \mathrm{~mm} \mathrm{~g} / \mu \mathrm{A} \mathrm{cm} \mathrm{yr}\right), \rho$ is the density $(4.51$ $\mathrm{g} / \mathrm{cm}^{3}$ ) and $\mathrm{EW}$ the equivalent weight (11.98 - dimensionless).

\section{RESULTS}

\section{Corrosion Potential and Corrosion Rate}

Figure 3 shows the evolution of the corrosion potential for Ti Gr 7 creviced specimens as a function of the immersion time in chloride plus fluoride (nitrate) solutions (Table 2). The $\mathrm{E}_{\text {corr }}$ increased as the time increased. The behavior of Ti Gr 7 was practically the same for the pure chloride solution (TG0206) and for the solution containing chloride and fluoride (TG0207). The potential started at approximately $-850 \mathrm{mV}$ SSC and increased approximately $300 \mathrm{mV}$ during the 24-hour immersion. For the third solution containing nitrate, the $\mathrm{E}_{\text {corr }}$ of Ti Gr 7 was slightly higher (TG0213).

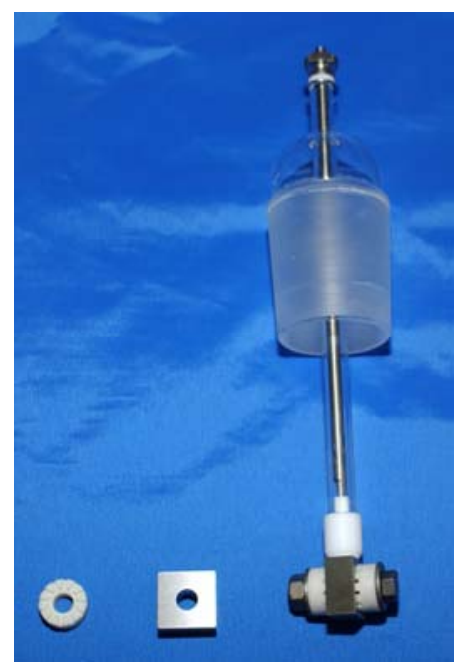

Figure 1. Specimen for Electrochemical Testing

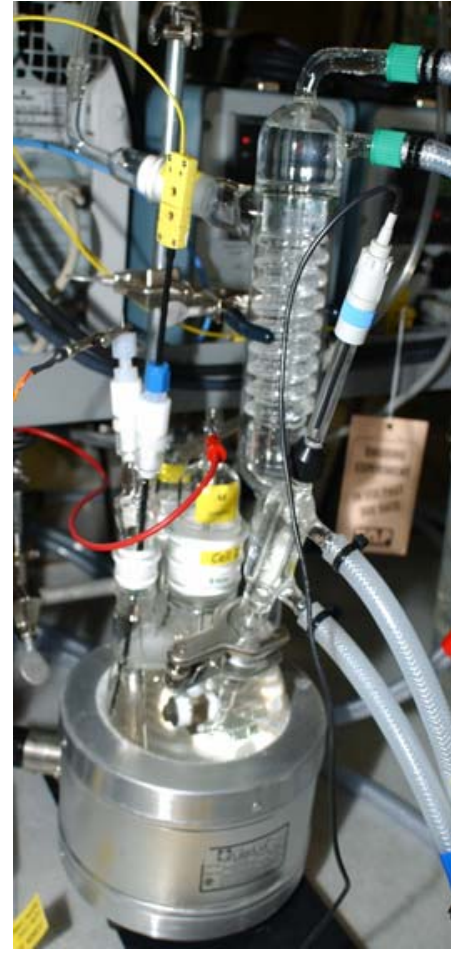

Figure 2.

Electrochemical Cell
Figure 4 shows the evolution of the corrosion potential as a function of immersion time for $\mathrm{Ti} \mathrm{Gr} 7$ in pure chloride solutions (TG0206) and in solutions containing different amounts of nitrate (Table 2). The higher the nitrate in the solution, the higher was the $\mathrm{E}_{\text {corr }}$.

Table 3 shows the corrosion potential and the corrosion rates at the end of the 24-hour immersion in the deaerated electrolytes. The corrosion potential and corrosion rates in Table 3 are for short-term immersion in deaerated brines and they may not represent the long-term behavior of Ti Gr 7 in aerated brines. Figure 5 shows the average corrosion rate of $\mathrm{Ti}$ 
Gr 7 for all the six tested electrolytes in Table 2 measured using the polarization resistance technique. The corrosion rate in all the six electrolytes was exceptionally low, on the order of 50 $\mathrm{nm} /$ year and lower. This could be a result of the technique used for calculating the corrosion rates. Previously reported corrosion rates for Ti Gr 7 in other brines were in the order $250-400 \mathrm{~nm} /$ year [13]. For the electrolytes at $110^{\circ} \mathrm{C}$ (Brines or electrolytes 1-5) the highest corrosion rate was in the solution that contained an intermediate amount of nitrate (Brine 2). Brines 4 and 5, which contained a small amount of fluoride, did not cause higher corrosion rates in the Ti Gr 7 specimens.

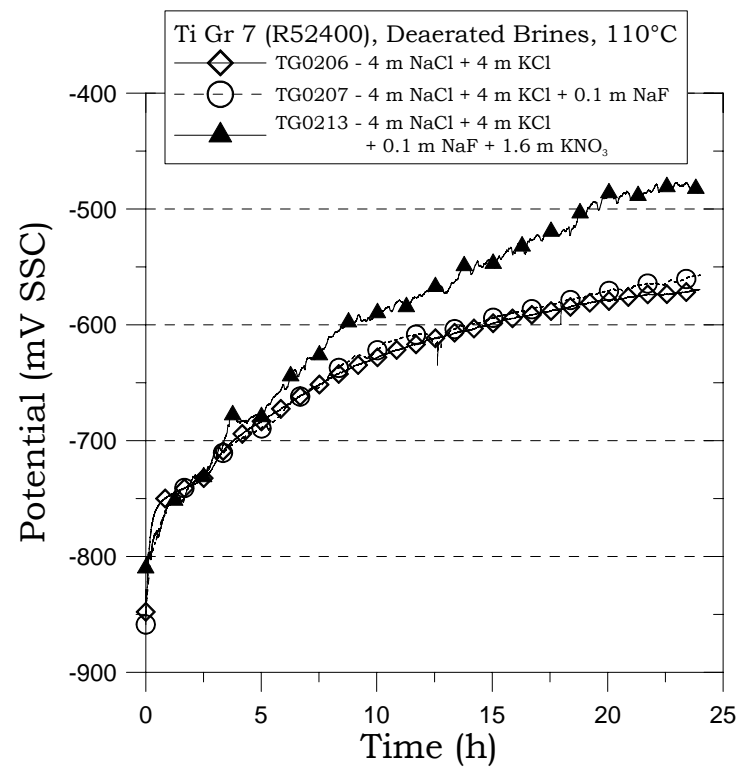

Figure 3. $E_{\text {corr }}$ vs. time. Effect of Fluoride

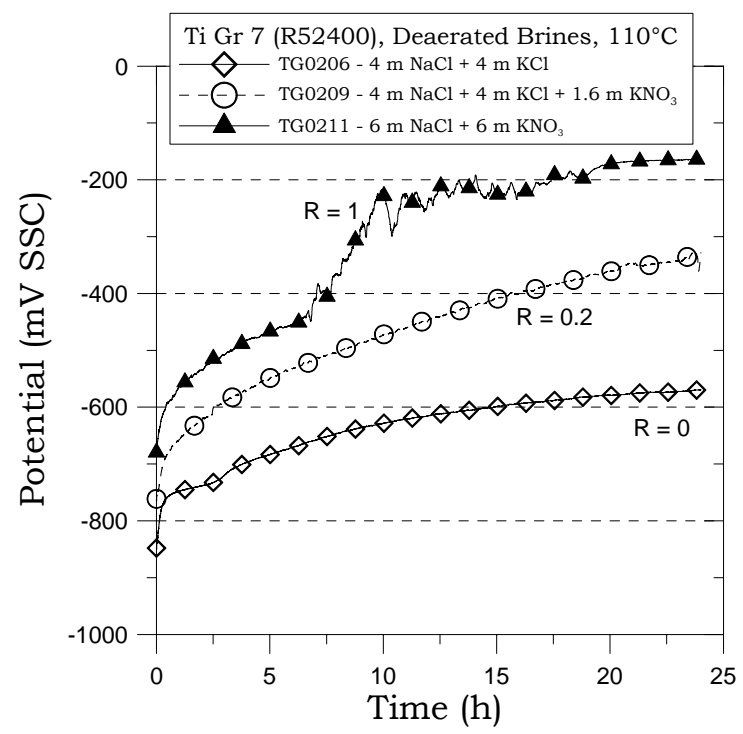

Figure 4. $E_{\text {corr }}$ vs. time. Effect of Nitrate
Current results suggest that the presence of $0.1 \mathrm{~m} \mathrm{NaF}$ in the 4 $\mathrm{m} \mathrm{NaCl}+4 \mathrm{~m} \mathrm{KCl}$ electrolytes did not cause an increase in the corrosion rate of Ti Gr 7 after the short term immersion. Previous results showed that fluoride was detrimental for the corrosion rate resistance of titanium alloys [6-8]. However, those solutions [7-8] were less concentrated in chloride $(1 \mathrm{M}$ $\mathrm{NaCl}$. It is likely that a higher concentration of chloride in the current tests counter effected the detrimental action of fluoride under open circuit potential conditions.

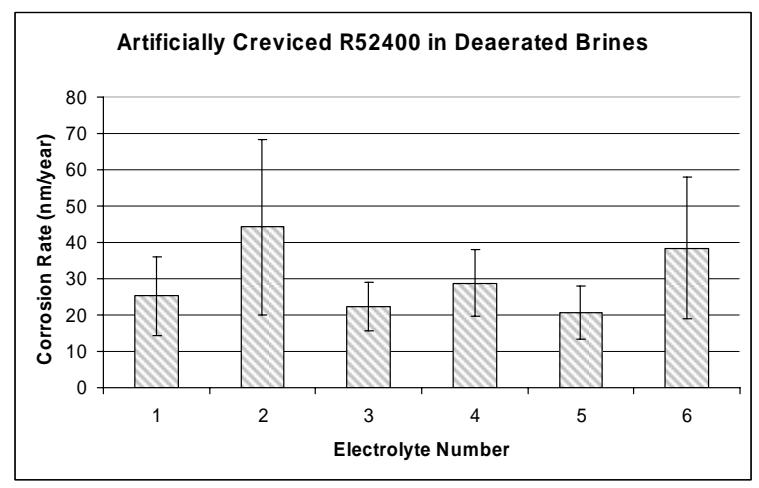

Figure 5. Average corrosion rate of $\mathrm{Ti} \mathrm{Gr} 7$

Table 3. Corrosion Potential and Corrosion Rates

\begin{tabular}{|l|c|c|}
\hline $\begin{array}{l}\text { Specimen } \\
\text { Electrolyte }\end{array}$ & $\begin{array}{c}E_{\text {corr }}(\mathrm{mV} \\
\mathrm{SSC})\end{array}$ & Corrosion Rate (nm/year) \\
\hline TG0206-1 & -570 & $19.6,30.0,42.06$ \\
\hline TG0214-1 & -354 & $11.4,19.1,29.1$ \\
\hline & & \\
\hline TG0209-2 & -328 & $48.3,68.0,72.2$ \\
\hline TG0212-2 & -285 & $11.9,21.7,43.3$ \\
\hline & & \\
\hline TG0208-3 & -487 & $10.5,18.6,25.3$ \\
\hline TG0211-3 & -164 & $23.3,28.3,27.9$ \\
\hline & & \\
\hline TG0207-4 & -557 & $17.5,31.6,35.8$ \\
\hline TG0215-4 & -453 & $19.0,28.7,40.4$ \\
\hline & & \\
\hline TG0210-5 & -486 & $14.2,16.8,22.8$ \\
\hline TG0213-5 & -484 & $23.0,14.4,33.1$ \\
\hline & & \\
\hline TG0205-6 & -474 & Not determined \\
\hline TG0216-6 & -598 & $17.2,42.5,55.7$ \\
\hline
\end{tabular}

\section{Cyclic Potentiodynamic Polarization (CPP)}

Figure 6 shows the cyclic potentiodynamic polarization of Ti Gr 7 in pure chloride solutions and in solutions containing fluoride (Table 2). The polarization curve was the same in both 
electrolytes from the corrosion potential to approximately -300 $\mathrm{mV}$ SSC. However for potentials higher than $-300 \mathrm{mV}$ the current for the specimen immersed in the solution containing fluoride was one order of magnitude higher than in the solution free of fluoride (Figure 7).

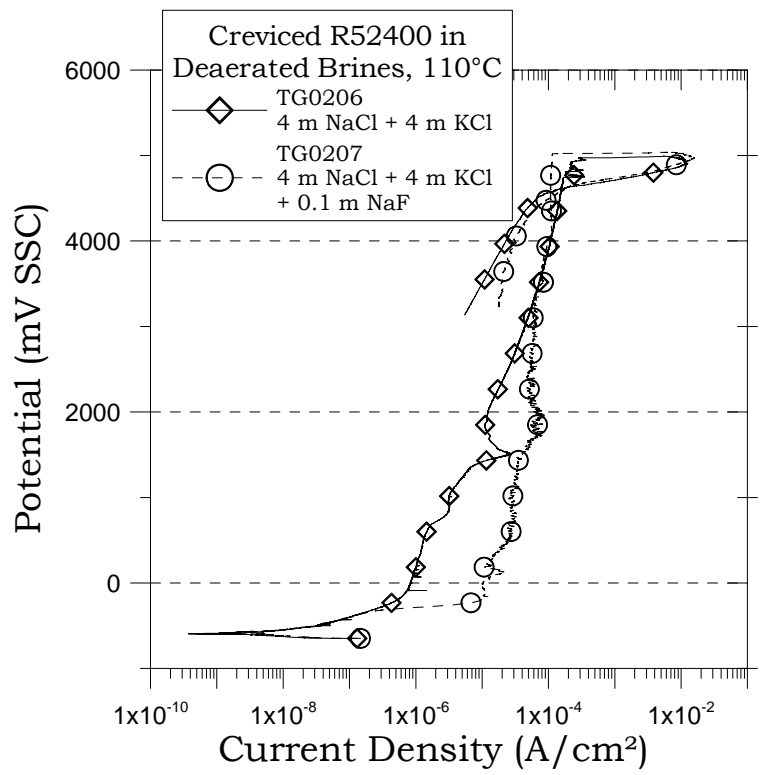

Figure 6. Cyclic polarization of Ti Gr 7, effect of fluoride

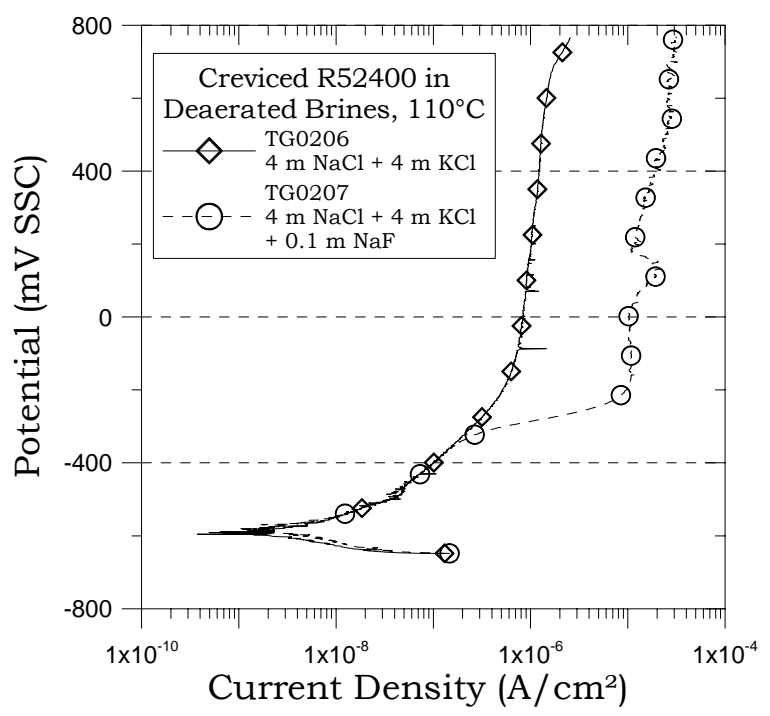

Figure 7. Cyclic polarization for $\mathrm{Ti} \mathrm{Gr} 7$ (Detail of Figure 6)

It has been shown above (Figure 5) that the corrosion rate (at the open circuit potential conditions) for $\mathrm{Ti}$ Gr 7 in the chloride and chloride plus fluoride solutions was practically the same. It is evident that a polarization of approximately $300 \mathrm{mV}$ above the corrosion potential was needed to increase the current on the Ti Gr 7 specimens immersed in the fluoride containing electrolyte. Figure 6 also shows that Ti Gr 7 can be polarized in both electrolytes ( 1 and 4 in Table 2 ) to potential values on the order of $5 \mathrm{~V}$ before final breakdown of the passive film occurs.

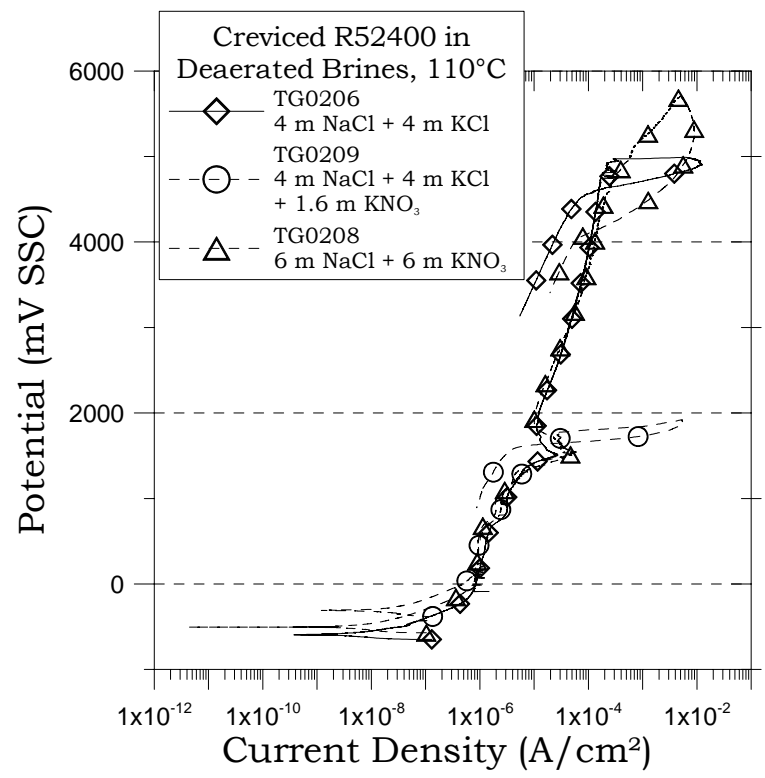

Figure 8. Cyclic polarization of Ti Gr 7, effect of nitrate

Figure 8 shows the cyclic polarization of $\mathrm{Ti} \mathrm{Gr} 7$ in Electrolytes $1-3$ at $110^{\circ} \mathrm{C}$. From the corrosion potential up to approximately $1.8 \mathrm{~V} \mathrm{SSC}$ the polarization curves in the three electrolytes ( $\mathrm{R}=0,0.2$ and 1$)$ was the same. Above $1.8 \mathrm{~V} \mathrm{SSC}$ the behavior in Electrolytes 1 and 3 was the same while the behavior in Electrolyte 2 it was different. The breakdown potential E200 (Table 4) in Electrolyte $2(\mathrm{R}=0.2)$ was 1813 $\mathrm{mV}$ while the E200 in Electrolytes 1 and 3 was $4764 \mathrm{mV}$ and $4482 \mathrm{mV}$, respectively. At this moment there is no explanation why the breakdown potential in the electrolyte with an intermediate amount of nitrate was lower than for either in pure chloride or in the high nitrate solutions.

Table 4 shows all the parameters from the CPP tests. The breakdown potential values E200 were higher than $4000 \mathrm{mV}$ SSC for all the tested conditions except for Electrolytes 2 and 5 (which contained the intermediate amount of nitrate). Even for the two tests in Electrolyte 6 at $140^{\circ} \mathrm{C}$ the E200 was above $4 \mathrm{~V}$ SSC. Values of potential this high do not have a physical meaning since the breakdown (decomposition) of water into oxygen and hydrogen occurs at potentials below $1 \mathrm{~V}$. That is, values breakdown potential (E20 and E200) and repassivation potential (ER10, ER1 and ERCO) higher than approximately $600 \mathrm{mV}$ in Table 4 are reported as illustrative only since in a naturally polarized environment these values of potentials are unachievable. 
Potential values data in Table 4 seem to show that the addition of fluoride to chloride solutions did not seem detrimental for the resistance of $\mathrm{Ti}$ Gr 7 to anodic polarization in the tested brines.

Table 4. Breakdown and repassivation potentials from CPP tests, mV SSC

\begin{tabular}{|l|c|c|c|c|c|}
\hline $\begin{array}{l}\text { Specimen } \\
\text { Electrolyte }\end{array}$ & E20 & E200 & ER10 & ER1 & ERCO \\
\hline TG0206 - 1 & 1483 & 4764 & 3505 & 2213 & 4611 \\
\hline TG0209-2 & 1425 & 1813 & 1628 & 1006 & 1649 \\
\hline TG0208-3 & 1458 & 4482 & 2990 & 1812 & 4140 \\
\hline TG0207-4 & 131 & 5023 & 553 & & 4510 \\
\hline TG0210-5 & 166 & 1806 & 125 & -160 & 1504 \\
\hline TG0205-6 & 1560 & 5997 & 4264 & 2665 & \\
\hline TG0216-6 & 1523 & 4786 & 3365 & 2149 & \\
\hline
\end{tabular}

Table 5. Observations after the CPP tests

\begin{tabular}{|l|l|}
\hline $\begin{array}{l}\text { Specimen } \\
\text { Electrolyte }\end{array}$ & \multicolumn{1}{|c|}{ Observations } \\
\hline TG0206 - 1 & $\begin{array}{l}\text { No crevice corrosion (CC). Massive } \\
\text { attack outside the crevice formers } \\
\text { (CF). White corrosion products }\end{array}$ \\
\hline TG0209 - 2 & $\begin{array}{l}\text { Localized corrosion (LC). Pitting } \\
\text { corrosion (PC) on specimen edges. }\end{array}$ \\
\hline TG0208-3 & LC outside CF, PC \\
\hline TG0207 - 4 & $\begin{array}{l}\text { LC around edges of CF. Attack at } \\
\text { specimen edges }\end{array}$ \\
\hline TG0210 - 5 & $\begin{array}{l}\text { LC on edges, white corrosion products, } \\
\text { PC outside CF }\end{array}$ \\
\hline TG0205 -6 & $\begin{array}{l}\text { Golden specimens, no LC, No CC, No } \\
\text { PC }\end{array}$ \\
\hline TG0216-6 &
\end{tabular}

Table 5 shows the type of attack suffered by the CPP tested specimens. In the pure chloride solution (Electrolyte 1) there was massive attack mostly on the edges of the specimens (Figure 9). This may have been a consequence of the high polarization applied to the specimen (Figure 6 and Table 4). The presence of fluoride (Electrolyte 4) promoted localized corrosion around the edges of the crevice formers (Figure 10). This phenomenon has been reported before in other chloride solutions [6-8]. The presence of nitrate (Electrolytes 2-3) seemed to have promoted pitting corrosion and localized corrosion outside the crevice formers (Figure 11). The amount of attack may have also been a consequence of the high applied potentials especially in Electrolyte 3 (Figure 8). The least amount of attack was for the Ti Gr 7 specimens tested in Electrolyte 6 at $140^{\circ} \mathrm{C}$ (Figure 12), which contained high amount of nitrate.

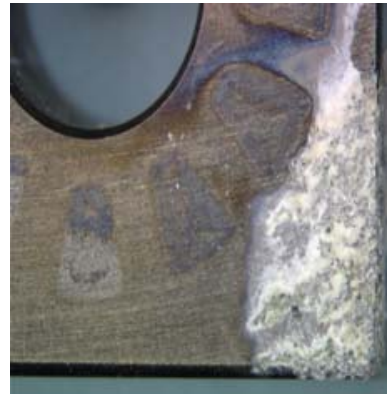

Figure 9. Specimen TG0206 after CPP test

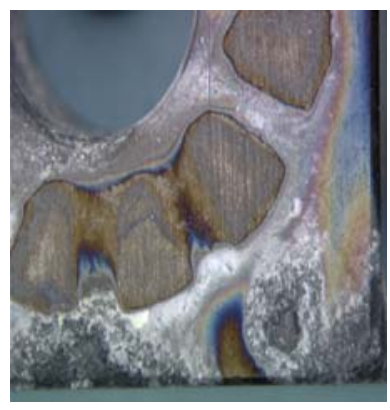

Figure 11. Specimen TG0208 after CPP test

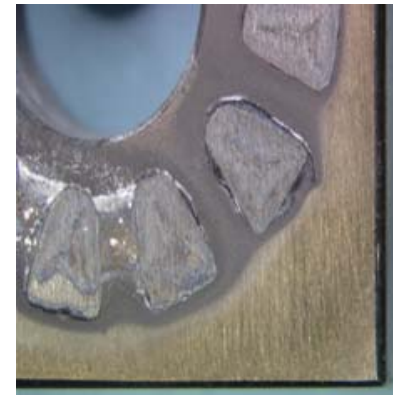

Figure 10. Specimen TG0207 after CPP test

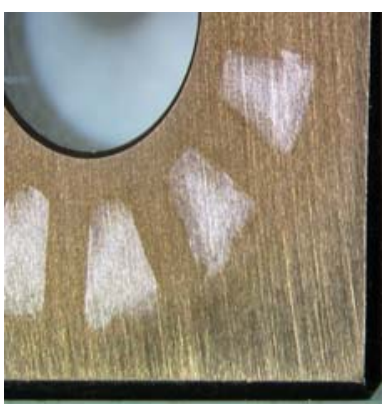

Figure 12. Specimen TG0216 after CPP test

\section{The THE Tests}

Figure 13 shows the THE test for specimen TG0214 in pure chloride solutions at $110^{\circ} \mathrm{C}$. During the galvanostatic period of 4 hours the potential continued to increase showing that the specimen became more passive during this treatment rather than nucleating crevice corrosion. The potential at the end of the galvanostatic period was $1397 \mathrm{mV}$ SSC. This potential is well above the potential for the stability of water and represents unattainable regions of polarization by natural means. During the further potentiostatic treatments, the current density continued to decrease, showing even further passivation.

Table 6 shows the type of attack suffered by the specimens after THE tests. The amount of attack was much smaller than in the case of the CPP tests (Table 5) mainly because smaller amount of charge was circulated through the THE tested specimens. The potentials reported in Table 6 are the values of potential at the end of the galvanostatic period. All these potential values are high, indicating again the resistance of $\mathrm{Ti}$ Gr 7 to localized corrosion under the tested conditions. 
Table 6. Results from the THE tests

\begin{tabular}{|l|c|l|}
\hline $\begin{array}{l}\text { Specimen } \\
\text { Electrolyte }\end{array}$ & $\begin{array}{c}\text { ER,CREV } \\
\text { mV SSC }\end{array}$ & $\begin{array}{l}\text { Observations after the } \\
\text { tests }\end{array}$ \\
\hline TG0214 -1 & $>1397$ & One corrosion pit \\
\hline TG0212-2 & $>1761$ & $\begin{array}{l}\text { Blue staining under } \\
\text { CF, no LC, no CC }\end{array}$ \\
\hline TG0211-3 & $>1407$ & No CC, No LC \\
\hline TG0215-4 & $>1030$ & LC around CF edges \\
\hline TG0213-5 & $>1760$ & $\begin{array}{l}\text { LC around CF edges, } \\
\text { white corrosion } \\
\text { products }\end{array}$ \\
\hline
\end{tabular}

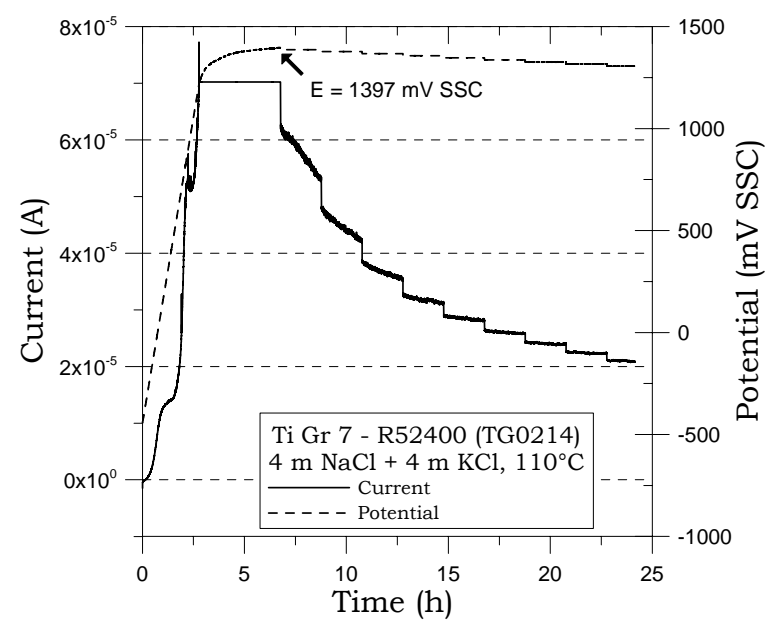

Figure 11. THE Test in pure chloride at $110^{\circ} \mathrm{C}$
Table 7. CPP Data for Ti Gr 7 and Alloy 22 at $110^{\circ} \mathrm{C}$

\begin{tabular}{|l|c|c|c|c|}
\hline Conditions & $\begin{array}{c}\text { E200 } \\
\text { Ti Gr 7 }\end{array}$ & $\begin{array}{c}\text { E200 } \\
\text { Alloy 22 }\end{array}$ & $\begin{array}{c}\text { ER1 } \\
\text { Ti Gr 7 }\end{array}$ & $\begin{array}{c}\text { ER1 } \\
\text { Alloy 22 }\end{array}$ \\
\hline $\begin{array}{l}4 \mathrm{~m} \mathrm{NaCl}+ \\
4 \mathrm{~m} \mathrm{KCl} \\
\mathrm{R}=0\end{array}$ & 4764 & 141,115 & $\begin{array}{c}2213 \\
\text { (LC) }\end{array}$ & $\begin{array}{c}-200,- \\
184(\mathrm{CC})\end{array}$ \\
\hline & & & & \\
\hline $\begin{array}{l}6 \mathrm{~m} \mathrm{Cl}^{-}+ \\
6 \mathrm{~m} \mathrm{NO}_{3}^{-}\end{array}$ & 4482 & 791,779, & $\begin{array}{l}1812 \\
\text { (LC) }\end{array}$ & $\begin{array}{c}373,522 \\
\text { (No CC) }\end{array}$ \\
\hline
\end{tabular}

\section{Summary and Conclusions}

- Ti Gr 7 had exceptionally low general corrosion rates in concentrated chloride, chloride plus fluoride and chloride plus nitrate brines at $110^{\circ} \mathrm{C}$ and $140^{\circ} \mathrm{C}$.

- Ti Gr 7 was resistant to crevice corrosion in all the tested sodium and potassium based brines

- Ti Gr 7 suffered localized corrosion on the specimen surface not covered by the crevice formers due to the high applied potentials.

- The presence of fluoride in the environment promoted localized corrosion around the crevice formers edges

- Ti Gr 7 can be polarized to potentials well above the potentials for the stability of water without breakdown of passivity

- Under the tested conditions Ti Gr 7 was more resistant to localized corrosion than Alloy 22

\section{ACKNOWLEDGMENTS}

\section{Comparative Behavior with N06022}

Table 7 shows comparatively the data from the CPP tests for both Ti Gr 7 and Alloy 22. Data for Alloy 22 is from Reference 14. Alloy 22 suffered crevice corrosion in the pure chloride solution $(\mathrm{R}=0)$ but did not suffer crevice corrosion in the solution containing nitrate $(\mathrm{R}=1)$. In the first case, the repassivation potential ER1 was low (approximately $-200 \mathrm{mV}$ SSC) but in the second case this value was higher than $350 \mathrm{mV}$. The type of attack that the Ti Gr 7 suffered after the CPP tests is given in Table 5. Even though the Ti Gr 7 suffered localized corrosion (LC) under the tested conditions (Table 7), the repassivation potentials ER1 were higher than $1.8 \mathrm{~V} \mathrm{SSC}$. The data in Table 7 shows the extreme resistance of Ti Gr 7 to crevice corrosion in concentrated chloride brines.
This work was performed under the auspices of the U.S. Department of Energy by the University of California Lawrence Livermore National Laboratory under contract W-7405-Eng-48. The work was supported by the Yucca Mountain Project, which is part of the DOE Office of Civilian Radioactive Waste Management (OCRWM).

\section{DISCLAIMER}

This document was prepared as an account of work sponsored by an agency of the United States Government. Neither the United States Government nor the University of California nor any of their employees, makes any warranty, express or implied, or assumes any legal liability or responsibility for the accuracy, completeness, or usefulness of any information, apparatus, product, or process disclosed, or represents that its use would not infringe privately owned rights. Reference herein to any specific commercial product, process, or service by trade name, trademark, manufacturer, or otherwise, does not 
necessarily constitute or imply its endorsement, recommendation, or favoring by the United States Government or the University of California. The views and opinions of authors expressed herein do not necessarily state or reflect those of the United States Government or the University of California, and shall not be used for advertising or product endorsement purposes.

\section{REFERENCES}

1. G. M. Gordon, Corrosion, 58, 811 (2002).

2. ASTM International, Annual Book of ASTM Standards, Volume 02.04 "Non-Ferrous Metals" Standard B-265 (West Conshohocken, PA: ASTM International, 2004).

3. R. W. Schutz, "Corrosion of Titanium and Titanium Alloys' in Metals Handbook, Volume 13B, p. 252 (ASM International, 2005).

4. Y. Sugizaki, K. Ueda, T. Yashiki, K. Mori, H. Yano and H. Satoh, Proc. Of the $4^{\text {th }}$ International Offshore and Polar Engineering Conference, Vol. IV, p. 238 (The International Society of Offshore and Polar Engineers, 1994).

5. R. W. Schutz, Corrosion, 59, 1043 (2003).

6. C. S. Brossia and G. A. Cragnolino, Corrosion 57, 768 (2001).

7. T. Lian, T. Yashiki, T. Nakayama, T. Nakanishi and R. B. Rebak, "Comparative Corrosion Behavior of Two Palladium-Containing Titanium Alloys," - Paper 93418 in the Proceedings of PVP2006-ICPVT-11, 2006 ASME Pressure Vessels and Piping Division Conference, July 2327, 2006, Vancouver, BC, Canada

8. T. Lian, T. Yashiki, T. Nakanishi, T. Nakayama and R. B. Rebak, "Comparative Localized Corrosion Behavior
Between High and Low Palladium Titanium Alloys," International High-Level Radioactive Waste Management Conference, Las Vegas, NV April 30 to May 04, 2006 (American Nuclear Society, La Grange Park, IL)

9. J. A. Rard, K. J. Staggs, S. D. Day and S. A. Carroll, "Boiling Temperature and Reversed Deliquescence Relative Humidity Measurements for Mineral Assemblages in the $\mathrm{NaCl}+\mathrm{NaNO}_{3}+\mathrm{KNO}_{3}+\mathrm{Ca}\left(\mathrm{NO}_{3}\right)_{2}+\mathrm{H}_{2} \mathrm{O}$ System” J. Solution Chemistry, 35, 1187-1215, 2006

10. C. R. Bryan, "Evolution of Waste Package Environments in a Repository at Yucca Mountain," presented the Nuclear Waste Technical Review Board Workshop on Localized Corrosion, 25-26 September 2006, Las Vegas, Nevada (http://www.nwtrb.gov/meetings/overheads.html).

11. ASTM International, Annual Book of ASTM Standards, Volume 03.02 "Wear and Erosion; Metal Corrosion" p. 91 (West Conshohocken, PA: ASTM International, 2004).

12. R. G. Kelly, J. R. Scully, D. W. Shoesmith and R. G. Buchheit "Electrochemical Techniques in Corrosion Science and Engineering," Page 126 (Marcel Dekker Inc. New Yoor, NY 2003).

13. F. Hua and G. Gordon, Corrosion, 60, 764 (2004).

14. T. Lian, G. E. Gdowski, P. D. Hailey, and R. B. Rebak, "Crevice Repassivation Potential of Alloy 22 in HighNitrate Dust Deliquescence Type Environments," - Paper 26164 in the Proceedings of PVP2007, ASME Pressure Vessels and Piping Division Conference, July 22-26, 2007, San Antonio, TX 